\title{
Consequences of large-scale salinity alteration during the Deepwater Horizon oil spill on subtidal oyster populations
}

\author{
Sean P. Powers ${ }^{1, *}$, Jonathan H. Grabowski ${ }^{2}$, Henry Roman ${ }^{3}$, Amelia Geggel ${ }^{3,+}$, \\ Shahrokh Rouhani ${ }^{4}$, Jacob Oehrig ${ }^{4}$, Mary Baker ${ }^{5}$ \\ ${ }^{1}$ Department of Marine Sciences, University of South Alabama and the Dauphin Island Sea Lab, 101 Bienville Blvd., \\ Dauphin Island, AL 36528, USA \\ ${ }^{2}$ Marine Science Center, Northeastern University, 430 Nahant Road, Nahant, MA 01908, USA \\ ${ }^{3}$ Industrial Economics, Inc., 2067 Massachusetts Ave., Cambridge, MA 02140, USA \\ ${ }^{4}$ NewFields, Inc., 1349 W. Peachtree Street, Suite 2000, Atlanta, GA 30309, USA \\ ${ }^{5}$ National Oceanic and Atmospheric Administration, Assessment and Restoration Division, 7600 Sand Point Way NE, Seattle, \\ WA 98115, USA
}

\begin{abstract}
Response actions associated with oil spills often have significant impacts on ecological communities. During the $87 \mathrm{~d}$ long Deepwater Horizon oil spill, the State of Louisiana (USA) released vast quantities of Mississippi River water into 2 estuarine basins (Barataria Bay and Black Bay/Breton Sound) in response to the approach of oil. We assessed the impact on subtidal oyster populations of this novel oil spill response action using 3 independent methods: (1) comparison of fisheries-independent post-spill densities to a pre-spill temporal baseline ${ }_{i}(2)$ comparison of oyster density collected during natural resource damage assessment sampling between the area of maximal freshwater impact and reference areas in the 2 basins; and (3) estimation from a doseresponse model derived from an analysis of an in situ mark and recapture study conducted in 2010 to assess the relationship between salinity and oyster mortality. A substantial portion of both basins ( $483 \mathrm{~km}^{2}$ of Barataria Bay and $362 \mathrm{~km}^{2}$ of Black Bay/Breton Sound) experienced prolonged periods of very low $(<5 \mathrm{ppt})$ salinity in 2010 that lasted at least 1 mo longer than the average duration of low salinity between 2006 and 2009. The 3 approaches all indicate that dramatic losses occurred in the number of market-sized (>75 mm) oysters as a result of a system-wide lowering of salinities, with an estimated 1.16 to 3.29 billion market-equivalent oysters lost. The efficacy of the large-scale response action of altering hydrographic conditions during the summer oyster growth period should be examined in light of the major perturbation to oyster communities.
\end{abstract}

KEY WORDS: Estuary · Oil spill response - Natural resources damage assessment · Oyster reefs · Gulf of Mexico $\cdot$ Crassostrea virginica $\cdot$ Hydrography

\section{INTRODUCTION}

Eastern oysters Crassostrea virginica are a critical component of many estuarine ecosystems, particularly those along the US Gulf and mid-Atlantic coasts (Beck et al. 2011), and are the quintessential estuarinedependent species, spending their entire life cycle within estuaries. Although eastern oysters have been

*Corresponding author: spowers@southalabama.edu

${ }^{\oplus}$ Deceased

${ }^{\S}$ Advance View was available online June 15, 2017 observed across a large range of salinities (3-36 ppt), they generally thrive in the narrow band of mesohaline water in an estuary (Melancon et al. 1998). This 'green band' of water formed by the interface between the sediment-laden, brown freshwater entering from riverine systems and runoff and the blue marine water ingression from the oceanic realm is a constantly fluctuating hydrographic zone of estuaries.

(C) S.P.P., J.H.G., H.R., A.G., S.R., J.O., and outside the USA the US Government 2017. Open Access under Creative Commons by Attribution Licence. Use, distribution and reproduction are unrestricted. Authors and original publication must be credited. Publisher: Inter-Research · www.int-res.com 
Too much freshwater reduces local salinity to levels where survivorship, growth, or reproduction of oysters is impaired, whereas too much ocean water generally elevates salinities and is associated with higher levels of predators (e.g. the oyster drill Stramonita haemastoma) or disease (e.g. the protozoan parasite Perkinsus marinus) that leads to reduced survivorship (e.g. Gunter 1955, Davis 1958, 1979, Chatry et al. 1983, Brown \& Richardson 1988, Soniat \& Brody 1988, Fodrie et al. 2008, La Peyre et al. 2009, 2013, Soniat et al. 2013). Although the specific thresholds of these triggers varied from study to study, the general pattern of oysters thriving in waters whose average annual salinities fall between 8 and 22 ppt with frequent brief pulses of freshwater input is well established and accepted by oyster biologists. Because settlement of oysters is gregarious on existing oyster shells, sustainable populations of oysters require that the position of this green zone of water stays relatively fixed over time. A substantial perturbation of this salinity zone away from areas of existing oyster shell cover, particularly at a time of increased water temperatures, can both hamper reproduction and result in oyster mortality that can have lasting impacts on the oyster fishery as well as affecting the ecological benefits that accrue from healthy oyster reefs.

On 20 April 2010, the Deepwater Horizon (DWH) exploded and set off an unprecedented chain of environmental perturbations in the northern Gulf of Mexico (GoM). Hundreds of millions of liters of oil were spilled into the GoM, resulting in the oiling of at least $2000 \mathrm{~km}$ of estuarine and coastal shorelines. In addition to the contaminant release, response actions taken by state and federal resource agencies to mitigate the environmental disaster also introduced potential environmental perturbations. The State of Louisiana, in response to the potential damage from the compromised well head, took the unprecedented action of releasing large quantities of freshwater through diversion structures along the Louisiana coastline to prevent the ingress of oil and to flush contaminants from where oil was likely to come ashore (Martínez et al. 2012). The Davis Pond and Caernarvon diversions were the 2 major diversion structures opened; these structures allow freshwater from the Mississippi River to flow into Barataria Bay and Black Bay/Breton
Sound, respectively. The Davis Pond diversion is located on the southwestern bank of the Mississippi River in St. Charles Parish, approximately $24 \mathrm{~km}$ (15 miles) upstream of New Orleans (US ACE, New Orleans District; www.mvn.usace.army.mil/About/Pro jects/DavisPondFreshwaterDiversion.aspx), while the Caernarvon diversion is situated on the east bank of the Mississippi River in Plaquemines Parish, downstream of New Orleans (LDNR 2003). The Caernarvon diversion was opened in response to the DWH spill on 23 April 2010 and remained open through the first 2 wk of August at or near maximum capacity ( $225 \mathrm{~m}^{3} \mathrm{~s}^{-1}$; Fig. 1). Davis Pond remained open from 8 May through 10 September 2010, with flow ranging from 200 to $275 \mathrm{~m}^{3} \mathrm{~s}^{-1}$.

Large-scale manipulation of hydrographic features is not a typical response to an oil spill; however, the scale of the DWH oil spill challenged conventional response activities both in the open ocean as well as in estuarine waters. Freshwater diversions are used to divert water from the Mississippi River to help enhance wetland vegetation and re-nourish marsh ecosystems (DeLaune et al. 2003). Normally, large quantities of freshwater are allowed to flow through the structures during the cooler winter and early spring months of each year because of potential impacts to oysters and other fisheries that would result from exposure to lower-salinity waters during the warmer summer months (Turner 2006, La Peyre et al. 2013, Rose et al. 2014). In 2010, these diversions remained opened for significantly longer and at a higher flow rate than in previous years.

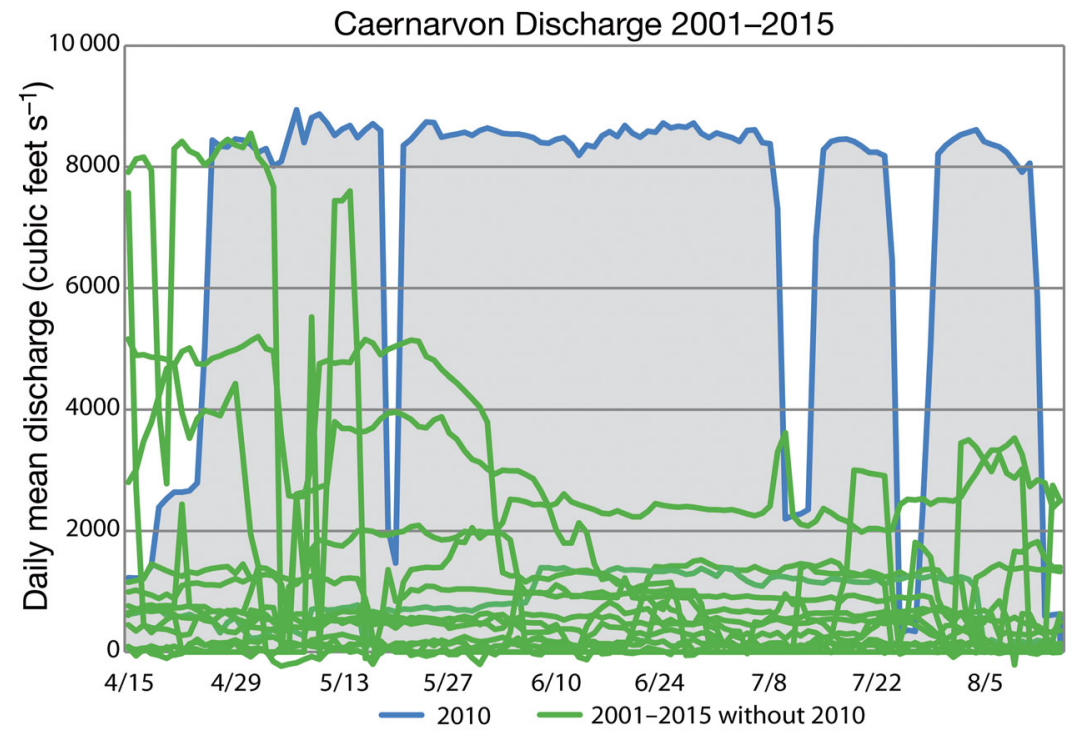

Fig. 1. Discharge of Mississippi River water from the Caernarvon freshwater discharge structure from 2001 to 2015 . Dates are given as month/day; 1 cubic foot $=0.028 \mathrm{~m}^{3}$ 
The introduction of substantial quantities of freshwater into an estuarine system, (e.g. due to a major storm event) would be expected to have substantive, albeit short-term (1-2 yr), consequences on oyster fishery resources in the 2 basins. In addition to their role in supporting a valuable US fishery, oysters are essential components of healthy estuarine ecosystems. Hence, changes in the abundance of oysters or the areal extent of oyster reef can have substantial ecological consequences. The suspension-feeding activity of oysters enhances benthic pelagic coupling and removes particulates from the water column, potentially increasing water clarity (see Coen et al. 2007 and Grabowski et al. 2012 for a complete list of ecological services). Reefs formed by the gregarious settlement of oysters provide ecological services including provision of habitat for fish and mobile invertebrates (Peterson et al. 2003), enhanced biogeochemical cycling (Piehler \& Smyth 2011), and shoreline stabilization (Scyphers et al. 2011).

As part of the DWH oil spill natural resources damage assessment (DWH NRDA), we performed an extensive assessment of the potential impacts of the large-scale introduction of freshwater on oyster resources in coastal Louisiana. Because the diversions were open as part of the DWH oil spill response activities, damages resulting from the diversion openings would be a legitimate component of the damage assessment, and US federal regulations require the public to be compensated for the damages. We conducted a multi-pronged assessment of the impact of these freshwater diversions on subtidal oyster populations in the northern GoM. Multiple analyses using both state fisheries-independent data and data collected as part of the DWH NRDA showed substantial impacts of the freshwater diversion releases on oyster populations in Barataria Bay and Black Bay/Breton Sound.

\section{MATERIALS AND METHODS}

We estimated injury by comparing oyster density (abundance $\mathrm{m}^{-2}$ ) in areas exposed to the 2010 Davis Pond and Caernarvon diversion openings against baseline oyster densities, where baseline is defined either as historical, pre-spill densities or as densities in post-spill areas unaffected by the diversions or other aspects of the DWH incident. We estimated injury in 2 basins: Barataria Bay basin to the west of the Mississippi River, which receives the outfall from the Davis Pond diversion, and Black Bay/Breton Sound basin to the east, which receives the outfall from the Caernarvon diversion. We assessed differences in post-spill and baseline densities using multiple methods and datasets to test the robustness and bracket the uncertainty of our injury results. Specifically, we applied 3 approaches to quantify subtidal oyster injury. The first approach compared post-spill densities measured by the Louisiana Department of Wildlife and Fisheries (LDWF) to a pre-spill temporal baseline ('fisheries temporal'). The second approach ('NRDA spatial') employed a spatial definition of baseline conditions, based on modeled estimates of exposure to low salinities in each basin. It assessed oyster density differences between the area of maximal freshwater impact and baseline areas in these basins, using data collected as part of the DWH NRDA in 2010. The third approach ('Nestier tray/NRDA') defined injured and baseline locations using historical modeled salinity conditions and a dose-response model of freshwater impacts on mortality derived from analysis of annual Louisiana Nestier tray studies in the affected basins (Table 1).

\section{Data sources}

Louisiana fisheries-independent density data

We obtained oyster densities from diver-collected quadrat samples collected in June and/or July of each year from 2006 to 2010 from the LDWF annual oyster stock assessment program. The sampling program consisted of 8 sites in Barataria Bay and 32 sites in Black Bay/Breton Sound within known reef areas of the public oyster seed grounds (Fig. 2). From 2006 to 2009, site density was characterized using two $1.0 \mathrm{~m}^{2}$ quadrats, except at cultch plant sites, where teams collected five $0.25 \mathrm{~m}^{2}$ quadrats (LDWF 2006, 2007, 2008, 2009, 2010). All density results from $0.25 \mathrm{~m}^{2}$ quadrats were scaled to $1.0 \mathrm{~m}^{2}$. Beginning in 2010, density was characterized using five $1.0 \mathrm{~m}^{2}$ quadrats at all sites. Samples were collected in July of each year at approximately the same location, with LDWF teams randomly placing quadrats after poling at site coordinates to ensure sampling occurred on oyster habitat. We compiled LDWF density data into 3 size categories: spat $(<25 \mathrm{~mm})$, seed $(25-75 \mathrm{~mm})$, and market (>75 $\mathrm{mm})$.

\section{DWH NRDA density data}

As part of the DWH NRDA efforts, oyster density data were collected from July to October 2010. Sam- 
Table 1. Summary of injury calculation inputs for the 3 approaches used in this study. NRDA: natural resources damage assessment, LDWF: Louisiana Department of Wildlife and Fisheries

\begin{tabular}{|c|c|c|c|c|c|}
\hline Method & Key data & $\begin{array}{l}\text { Year(s) data } \\
\text { collected }\end{array}$ & Baseline & Injury area & Injury calculation \\
\hline $\begin{array}{l}\text { Fisheries } \\
\text { temporal }\end{array}$ & $\begin{array}{l}\text { LDWF fisheries } \\
\text { abundance data } \\
\text { (oysters } \mathrm{m}^{-2} \text { ) }\end{array}$ & 2006-2009, 2010 & $\begin{array}{l}\text { Based on historical } \\
\text { data: avg. oyster } \\
\text { densities 2006-2009 }\end{array}$ & $\begin{array}{l}\text { Area where oysters are } \\
\text { likely to occur }\end{array}$ & $\begin{array}{l}\text { Avg. difference } \\
\text { between density in } \\
2010 \text { and historical- } \\
\text { baseline } \times \text { basin area }\end{array}$ \\
\hline \multirow[t]{2}{*}{$\begin{array}{l}\text { NRDA } \\
\text { spatial }\end{array}$} & $\begin{array}{l}\text { NRDA abundance } \\
\text { data (oysters } \mathrm{m}^{-2} \text { ) }\end{array}$ & 2010 & $\begin{array}{l}\text { Avg. densities of } \\
\text { sites outside of } \\
\text { freshwater polygon }\end{array}$ & \multirow{2}{*}{$\begin{array}{l}\text { FW polygons defined by } \\
\text { areas with }>30 \text { additional } \\
\text { consecutive days with salin- } \\
\text { ity }<5 \text { ppt in } 2010 \text { compared } \\
\text { to historical time periods }\end{array}$} & \multirow{2}{*}{$\begin{array}{l}\text { Survival difference } \\
\text { between avg. } \\
\text { density in vs. out of } \\
\text { freshwater polygon }\end{array}$} \\
\hline & Predicted salinity & 2006-2009, 2010 & 2006-2009 & & \\
\hline $\begin{array}{r}\text { Nestier } \\
\text { NRDA }\end{array}$ & $\begin{array}{l}\text { Louisiana state } \\
\text { Nestier tray dataset } \\
\text { Predicted salinity } \\
\text { NRDA densities } \\
\text { (oysters } \mathrm{m}^{-2} \text { ) }\end{array}$ & $\begin{array}{c}2010 \\
2007-2009,2010 \\
2010\end{array}$ & $\begin{array}{l}\text { Back-calculated NRDA } \\
\text { densities using calculated } \\
\text { survival rates at NRDA } \\
\text { site locations }\end{array}$ & $\begin{array}{l}\text { Areas that indicated a de- } \\
\text { crease in survival in } 2010 \\
\text { compared to historic periods } \\
\text { based on the Nestier dose- } \\
\text { response curve }\end{array}$ & $\begin{array}{l}\text { Avg. survival } \\
\text { difference } \times \text { avg. } \\
\text { baseline density }\end{array}$ \\
\hline
\end{tabular}

pling consisted of up to 8 diver-collected quadrats at $200 \mathrm{~m}^{2}$ study sites in Barataria Bay (8 sites) and Black Bay/Breton Sound (8 sites; Fig. 2). Because this study focused on subtidal oyster injury, sites where oyster habitat typical of nearshore or intertidal oysters was observed were excluded $(<5 \%)$. The NRDA sample sites included some of the regularly sampled LDWF stock assessment sites plus additional Barataria Bay sites periodically sampled by LDWF. NRDA quadrat sampling locations were randomly generated from oyster habitat areas identified at these sites following side-scan sonar surveys of each site. Field teams used both 0.25 and $1.0 \mathrm{~m}^{2}$ quadrats, with the larger size used where oyster habitat was less contiguous. Quadrat samples were enumerated by size class for spat-, seed-, and market-sized oysters using the same definitions applied to the LDWF data. Density results from $0.25 \mathrm{~m}^{2}$ quadrats were scaled to estimate density per $1.0 \mathrm{~m}^{2}$.

\section{Louisiana Nestier tray data}

We obtained data from annual oyster Nestier tray survival studies conducted by LDWF for the years 2007 to 2012. These studies measured the survival of oysters experiencing various salinity regimes. In January of each year, LDWF deployed $70 \times 70 \times 7.6 \mathrm{~cm}$ Nestier trays on the seafloor at a range of distances from the Davis Pond and Caernarvon freshwater diversion outfalls (Fig. 3). Each tray included 20 seedsized (25-74 mm shell height) oysters collected from the basin where the tray was deployed. Oysters were affixed to the tray in a grid. After deployment, LDWF examined the oysters on each tray during monthly site visits and recorded data on individual oyster sta-

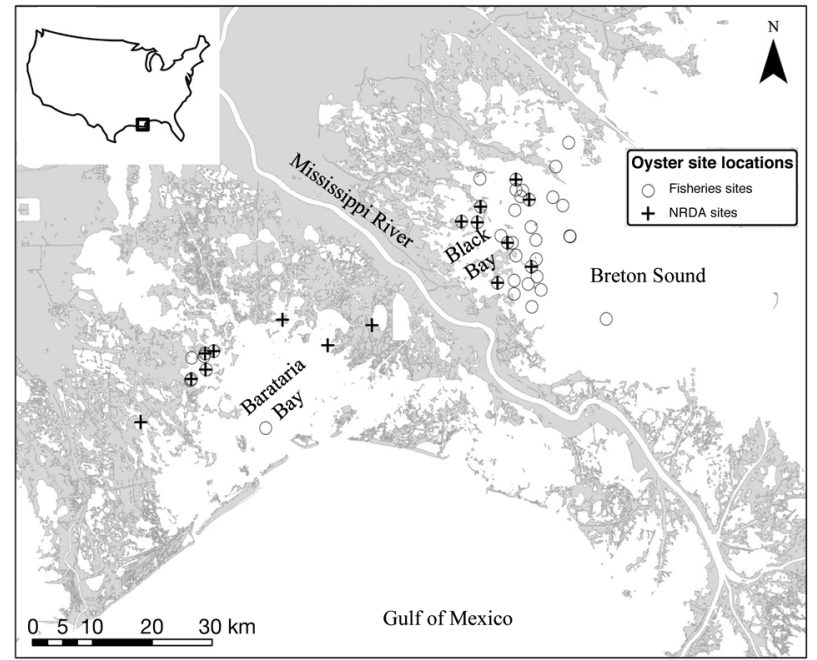

Fig. 2. Oyster sampling locations for the Louisiana Department of Wildlife and Fisheries (LDWF) fisheries data and the natural resources damage assessment (NRDA) studies

tus (alive, dead, or missing; the latter was excluded from our calculations), oyster growth, bottom salinity, and water temperature (P. Banks pers. comm.).

\section{Predicted daily salinity}

Daily average salinities and temperatures for 2006 through 2012 were estimated on a $200 \times 200$ m gridcell basis using a spatio-temporal kriging model (Szpiro et al. 2009, Lindstrom et al. 2011) fit to an extensive database of water quality observations in Barataria Bay and Black Bay/Breton Sound (McDonald et al. 2015). The model employed both continuous (hourly or daily) monitoring data as well as discrete 


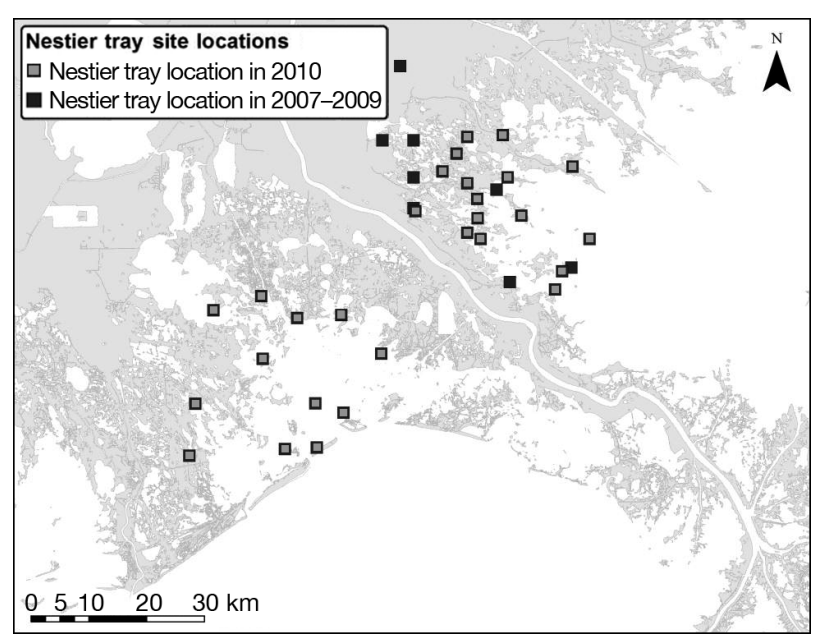

Fig. 3. Geographic extent of sites used in the Nestier tray/ natural resources damage assessment (NRDA) approach. The majority of sites display 2010 (light grey) sample locations co-occurring with some 2007-2009 (black) sample locations. See Fig. 2 for further details

(sporadically collected) measurements of water quality from 2006 through 2010, including measurements recorded during DWH NRDA oyster sampling. The model included data collected by LDWF, Louisiana Coastal Protection and Restoration Authority, Louisiana Department of Health and Hospitals, Louisiana Department of Environmental Quality, Mississippi Department of Environmental Quality, and United States Geological Survey (Fig. 4). habitat mapping using poling at randomly selected $200 \mathrm{~m}^{2}$ sites in both Barataria Bay and Black Bay/Breton Sound (Roman \& Stahl 2015). For areas in the possible oyster habitat stratum, percent cover estimates were generated from 2014 side scan sonar surveys conducted by DWH NRDA teams at randomly selected $200 \mathrm{~m}^{2}$ sites within both basins. For this stratum, percent cover was further stratified based on the presence or absence of oyster leases in the mapping area. Louisiana has an extensive system of leasing sea floor bottom for cultivation of oysters. Lease holders often relay cultch material with oyster spat from highsalinity areas to lease areas for oyster grow out.

\section{Injury calculation}

The injury calculation approaches we employed require 4 basic steps: (1) establishing baseline conditions of oysters unaffected by the freshwater diversion openings; (2) identifying the areas exposed to freshwater from the 2010 diversion openings; (3) comparing post-spill densities against baseline densities; and (4) scaling spill-related density changes across all oyster habitat in the exposed areas (Table 1).

\section{Fisheries temporal assessment}

The fisheries temporal approach estimated oyster injury by comparing oyster densities in 2010 in

\section{Percent cover}

Percent cover of oyster habitat was estimated for 2 strata within our study area (Fig. 5). One stratum covers 'known/likely oyster habitat,' which includes habitat previously mapped by Louisiana and habitat recommended by state biologists as highly likely to contain productive habitat based on historical harvest activity. The other represents 'possible oyster habitat,' where characteristics such as depth and salinity are sufficient to support oyster habitat, but where no a priori evidence of oyster habitat existed. Two sources provided percent cover estimates in the first stratum: 2010 LDWF side-scan sonar mapping in a portion of Black Bay/Breton Sound ('LDWF' stratum), and 2011 DWH NRDA oyster

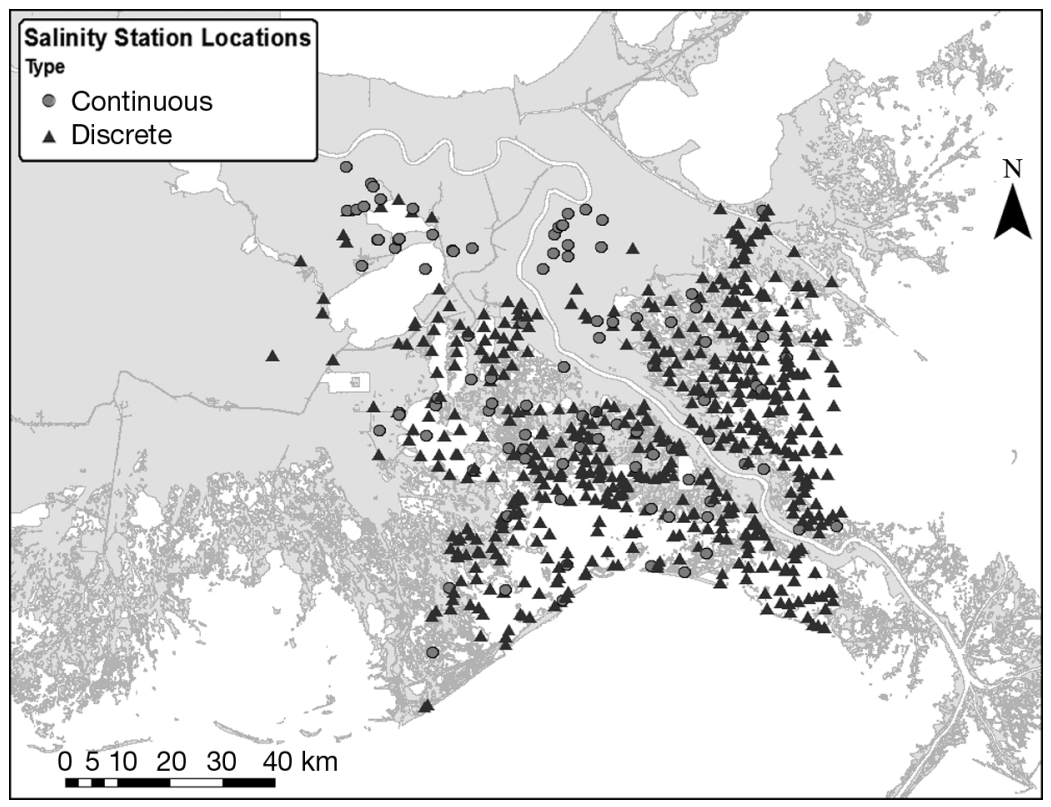

Fig. 4. Salinity sampling and monitoring stations in the study area. See Fig. 2 for further details 


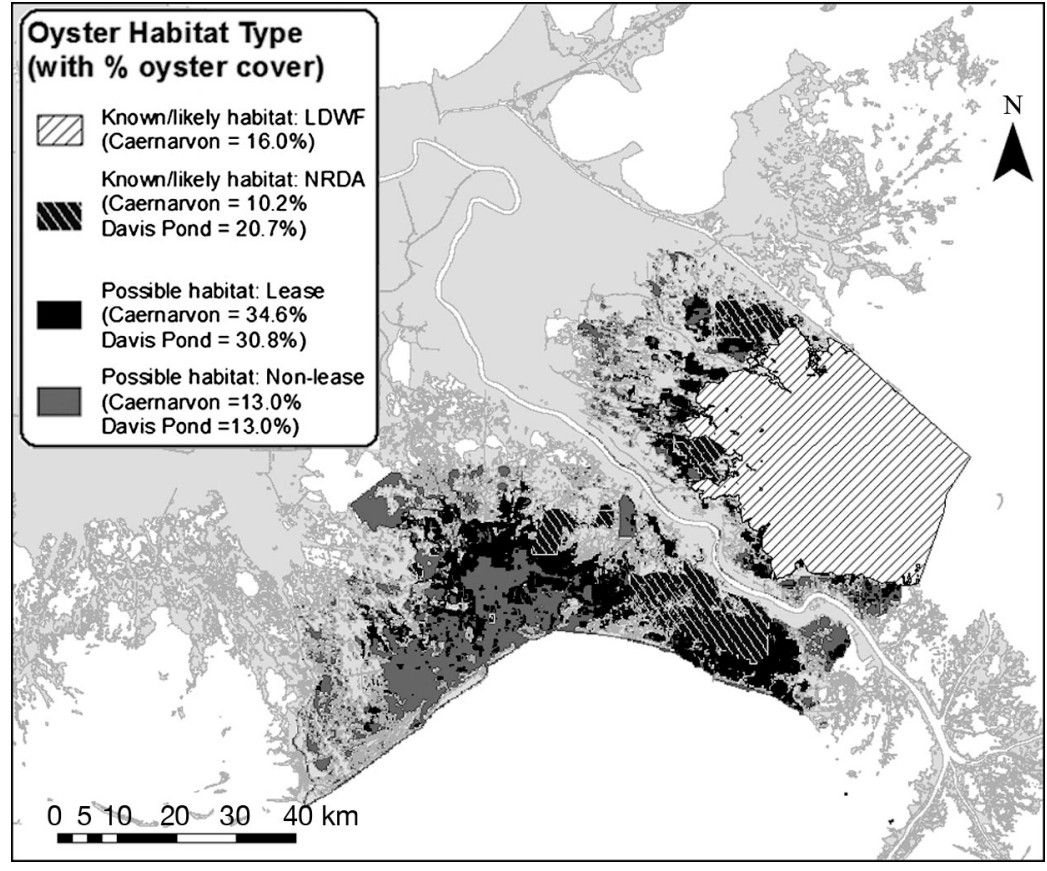

Fig. 5. Geographic extent of oyster strata and estimated reef percent cover. See Fig. 2 for further details

the affected basins to historical (pre-spill) average baseline densities in those basins from 2006 through 2009. Both the 2010 and baseline oyster densities were derived from the LDWF fisheries independent annual monitoring data; the baseline starting year of 2006 was selected so that the baseline would accurately reflect oyster densities following Hurricane Katrina, which could have disrupted or relocated oyster habitat.

The baseline data set for each basin included average densities derived from individual measurements from all LDWF sites in that basin reporting density data in at least 2 of the pre-spill years (6 sites in Barataria Bay and 29 sites in Black Bay/Breton Sound). Differences in densities for spat-, seed-, and market-sized oysters were calculated for each basin separately, scaled to the corresponding injury area, and then summed. Oyster losses were scaled by first estimating the area of oyster habitat in $\mathrm{m}^{2}$ in each basin and then multiplying that habitat area by the average density loss in oysters $\mathrm{m}^{-2}$. The area of oyster habitat is estimated by multiplying the area of each sampling stratum shown in Fig. 5 by the corresponding percentage of area in that stratum covered by oyster habitat and then summing across strata. The general formula for this calculation was:

Oyster loss $=\left(\right.$ Density $_{(2006-2009)}-$ Density $\left._{2010}\right) \times \sum$ Area $_{\text {stratum }} \times \%$ cover $_{\text {stratum }}$
This calculation was performed for each size class. We also calculated an overall number of 'market equivalent' oysters, by assuming $56 \%$ of the lost seed oysters and $30 \%$ of the lost spat would have survived to market size, based on mortality functions derived from data in Soniat et al. $(2012,2014)$ and Duke (2008). We then added those losses to the lost market oysters to obtain a total market equivalent oyster loss. As a lower bound on this type of analysis, we also estimated the fisheries temporal-based injury using only the fisheries-independent sites that fell within the low-salinity impact polygon described in the NRDA spatial assessment approach below.

\section{NRDA spatial assessment}

The NRDA spatial assessment approach delineated the exposed and baseline areas based on the modeled average daily salinity estimates described above. The injury was estimated by comparing densities observed during NRDA sampling events within and outside of the low-salinity exposure areas in each basin in 2010 . Both baseline and injured area densities were measured as part of the DWH NRDA in 2010.

We used the results of the spatio-temporal salinity model to delineate polygons in both Barataria Bay and Black Bay/Breton Sound that describe areas of substantial freshwater impact in 2010 relative to historical conditions. Exposures were determined based on interpolated average daily salinities between 27 April and 15 September. This is when the freshwater from the diversions would have reached the study area, and is therefore considered the 'critical time' period. For each $200 \mathrm{~m}^{2}$ grid cell in the salinity model, the maximum number of consecutive days below 5 ppt during the critical time period was calculated for each year between 2006 and 2010. Brief periods when average daily salinities were above $5 \mathrm{ppt}$ for less than $3 \mathrm{~d}$ were ignored in the computation of maximum number of consecutive days; such events were not common in the data set. For each grid cell, the maximum number of consecutive days was averaged for the years 2006 to 2009 as the 'historical condition.' If the difference between the historical condition and the 2010 average was more than $30 \mathrm{~d}$, the grid cell was considered affected. Thus, the 
polygon of all affected grid cells represents the area with a significant increase in prolonged low-salinity exposure in 2010. The difference of $30 \mathrm{~d}$ was selected to maximize the difference between average salinities inside and outside the polygon in 2010, thereby representing the greatest low-salinity impact.

For each size class in 2010, we calculated the difference in oyster densities between areas inside (exposed) and outside (baseline) of the impact polygons described above. The seedsize oyster density in Barataria Bay was higher inside the freshwater-impact polygon than outside. This value was considered as 'no injury' and treated as a 0 in the subsequent injury analysis. Oyster loss was scaled by adjusting the injured area for percent cover of oyster habitat. We employed the following general equation:

$$
\begin{aligned}
& \text { Oyster loss }=\left(\text { Density }_{\text {out }}-\text { Density }_{\text {in }}\right) \\
& \times \sum \text { Injured area }_{\text {stratum }} \times \% \text { cover }_{\text {stratum }}
\end{aligned}
$$

Seed and spat losses were scaled to market equivalents as described in the fisheries temporal approach and summed with the lost market oysters.

\section{Nestier tray/NRDA assessment}

Data from annual oyster Nestier tray studies conducted by LDWF were used to develop doseresponse curves linking oyster survival with freshwater exposures during the months of April to September for Nestier tray locations in both Barataria Bay and Breton Sound basins. Doses were measured as the maximum number of consecutive days of salinity below 5 ppt over the April to September time period at each Nestier tray location. This was computed using the year-specific spatial-temporal model results for the grid cell closest to each Nestier tray location.

We limited dose-response modeling to Nestier tray sites with at least $50 \%$ oyster survival as of the April status assessment in each given year to avoid including sites with high mortality due to factors other than summer freshwater exposure. In addition, 4 Barataria Bay Nestier sites classified as marine ( $10 \%$ of sites) were excluded, as these sites may have experienced increased mortality resulting from enhanced predation or increased disease due to their more saline waters (Gunter 1955). We developed dose-response curves for the period from 2007 through 2012, (excluding 2010), as well as for 2010 only. In the curve-fitting process, we set the dose-response

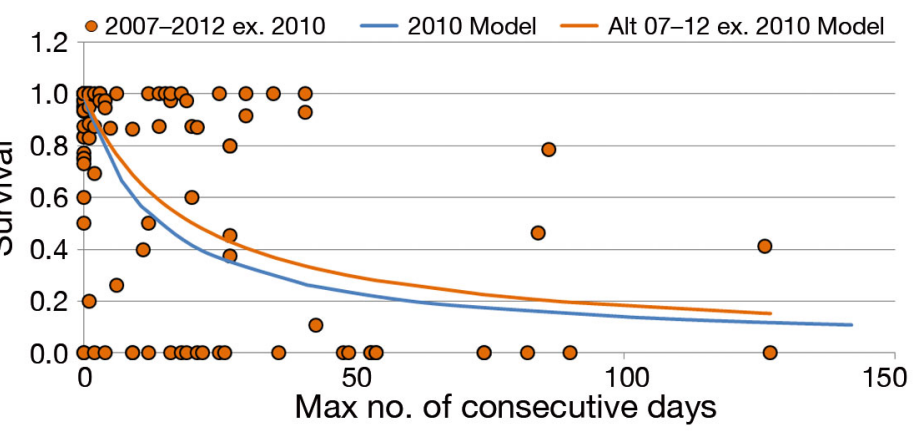

Fig. 6. Dose-response curve demonstrating the relationship between yster survivorship and number of days below 5 ppt salinity. ex.: excluding

curves to $100 \%$ survival at the 0 consecutive days of low salinity. We found little difference between the fitted dose-response curves developed for specific years; thus, our analysis uses the 2010 curves, since those represent relationships between salinity and survival in the year of interest (Fig. 6).

Using the 2010 dose-response curves and results from the salinity model, the decrease in the oyster survival rate in each $200 \mathrm{~m}^{2}$ grid cell due to the 2010 freshwater diversion exposures was calculated as the difference between survival rate based on the maximum number of consecutive low-salinity days in 2010 and the survival rate based on the average historical (2006-2009) maximum of consecutive low-salinity days in the same cell. Grids with higher predicted survival in 2010 than prior years were assumed to have a 0 decrease in survival. Declines in the survival rate were then averaged across all grid cells within each basin and oyster habitat stratum.

Baseline oyster density values were derived from NRDA quadrat oyster density results collected in 2010. The survival difference ( $\Delta$ Survival) for each NRDA quadrat location was calculated from the dose-response curves as described above. The prespill density values for each NRDA quadrat location were estimated using the following equation:

$$
\text { Density }_{\text {pre-spill }}=\frac{\text { Density }_{2010}}{1-\Delta \text { Survival }}
$$

Baseline oyster densities were then computed as the average estimated pre-spill density per basin.

The number of oysters lost per $\mathrm{m}^{2}$ was determined as the product of the average change in the survival rate in 2010, the area of oyster habitat experiencing decreases in survival in 2010, and the average baseline density estimated from the NRDA sites. We used the following general equation to calculate the oyster loss: 
Loss $=\Delta$ Survival $\times$ Density baseline

$\times \sum$ (Impacted area $_{\text {stratum }} \times \%$ cover $_{\text {stratum }}$

Losses were estimated by size class and converted to market equivalent oysters in the same manner described above.

\section{RESULTS}

\section{Salinity area of impact}

Major changes in the hydrographic regime of both the Barataria and the Back Bay/Breton Sound basins were observed during the summer of 2010 . The change in the number of consecutive days where mean salinity fell below 5 ppt was dramatic: on average, locations in the study area averaged 20.3 additional consecutive days of very low salinity $(<5 \mathrm{ppt})$ in 2010, compared to average historical values, with a maximum of $138 \mathrm{~d}$. The vast majority of the mesohaline areas of both basins experienced extended periods ( $>30 \mathrm{~d}$ ) of salinity $<5 \mathrm{ppt}$. The extent of the area of freshwater impact, defined as areas experiencing more than 30 consecutive days of salinities $<5$ ppt in 2010 when compared to historical baseline salinities, covered $483 \mathrm{~km}^{2}$ in Barataria Bay and $362 \mathrm{~km}^{2}$ in Black Bay/Breton Sound. When exposure is measured in terms of total days $<5$ ppt (i.e. not necessarily consecutive), the area of influence expands to $528 \mathrm{~km}^{2}$ in Barataria and $424 \mathrm{~km}^{2}$ in Black Bay/ Breton Sound.

\section{Oyster losses}

All 3 approaches to estimating oyster injury found substantial losses of oyster populations in the sub-

Table 2. Affected area, reef percent cover, and oyster densities by approach and basin. FW: freshwater, FID: fisheries-independent data,

OH: oyster habitat, LDWF: Louisiana Department of Wildlife and Fisheries, NRDA: natural resources damage assessment

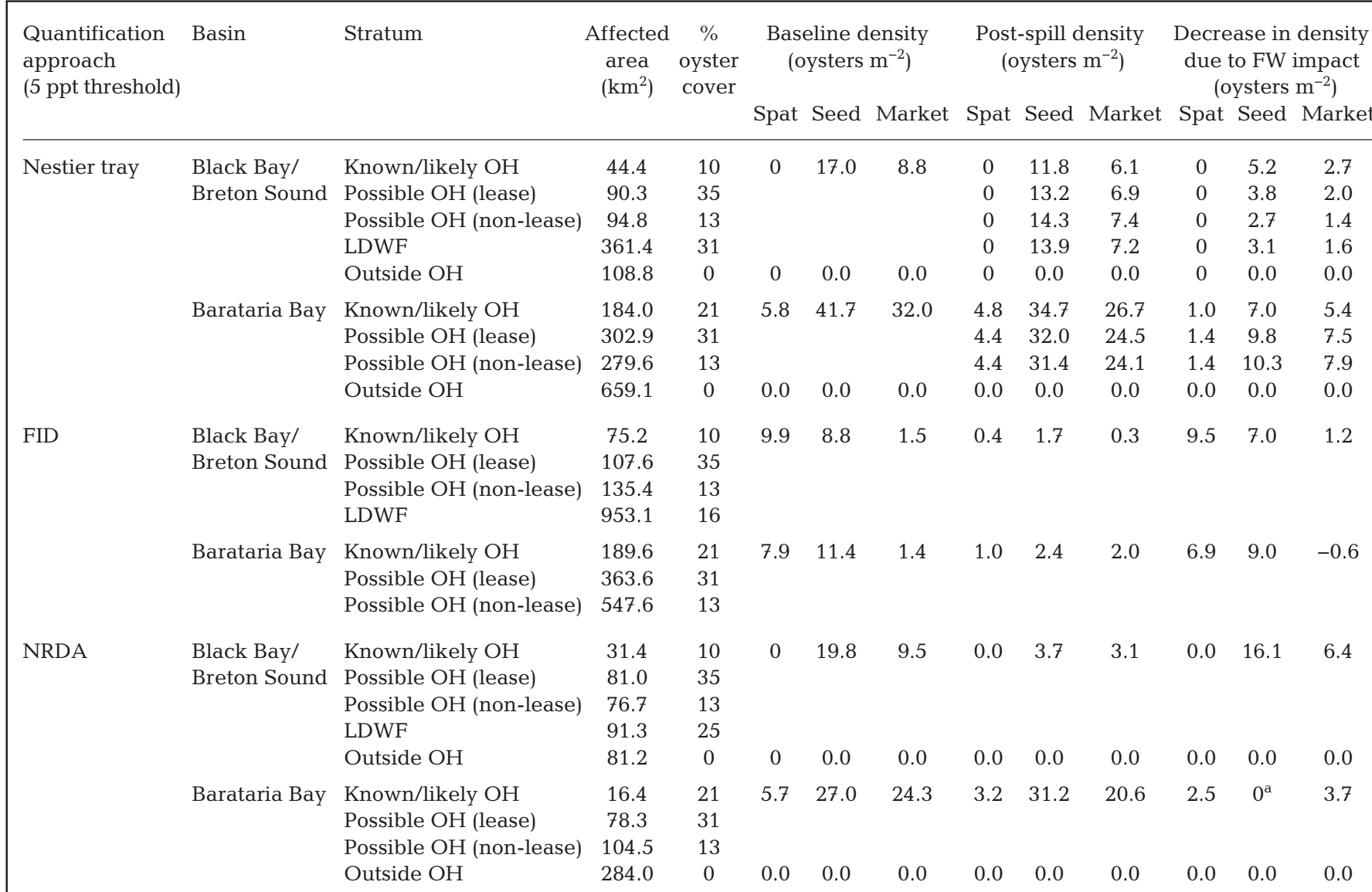

aThe seed-size oyster density in Barataria Bay increased, according to the NRDA sample data. This value was considered as 'no injury' and treated as a 0 in the injury analysis 
Table 3. Estimates of oysters killed as a result of lowered salinities during summer of 2010 by approach and oyster size class. NRDA: natural resources damage assessment, FW: freshwater

\begin{tabular}{|lcccccc|}
\hline \multirow{2}{*}{$\begin{array}{l}\text { Consecutive } \\
\text { days approach }\end{array}$} & \multirow{2}{*}{ FW } & \multicolumn{4}{c}{ Oyster losses in $2010\left(10^{6}\right.$ oysters $)$} \\
\cline { 5 - 7 } & & Market + seed & Market & Seed & Spat & Market equivalent \\
\hline Fisheries temporal assessment & - & 3642 & 130 & 3512 & 3573 & 3169 \\
NRDA spatial assessment & $5 \mathrm{ppt}$ & 1431 & 560 & 1025 & 101 & 1164 \\
Fisheries in freshwater polygon & $5 \mathrm{ppt}$ & 1164 & 142 & 1022 & 1389 & 1131 \\
Nestier tray/NRDA & $5 \mathrm{ppt}$ & 3543 & 1465 & 2078 & 216 & 2694 \\
\hline
\end{tabular}

tidal freshwater impact zone in 2010 (Tables 2 \& 3). The simplest approach, fisheries temporal, demonstrated a substantial decline in oysters in 2010 compared to pre-spill years. Compared to baseline values derived from the measured average densities in summer quadrat surveys from 2006 to 2009, oyster densities decreased in 2010 by $70 \%$ (market) to $100 \%$ (seed and spat) in Black Bay/Breton Sound (Table 2). Similar density declines were seen for spat and seed in Barataria Bay; however, market-sized oysters increased slightly $\left(+0.6\right.$ oyster $\left.\mathrm{m}^{-2}\right)$. These changes in density over the large area of likely oyster habitat (mapped reefs, lease areas, and non-lease areas outside mapped resource) in Barataria Bay (1101 km²) and Black Bay $\left(1271 \mathrm{~km}^{2}\right)$ resulted in the loss of an estimated $3.2 \times 10^{9}$ market equivalent oysters (Table 3), where market equivalent oysters are the sum of market-sized oysters lost plus the lost spat and seed that would be expected to survive to market size over the next 1 or 2 yr. Restricting our extrapolation of injury to the portions of the 2 basins that lie within the 5 ppt injury polygons resulted in smaller injured areas $\left(483 \mathrm{~km}^{2}\right.$ for Barataria Bay and $362 \mathrm{~km}^{2}$ for Black Bay/Breton Sound). The resulting lower bound injury estimate in market equivalent oysters was 1.1 $\times 10^{9}$ market equivalent oysters (see 'Fisheries in freshwater polygon' in Table 3).

The results for the NRDA spatial approach reflect the oyster abundance differences between NRDA sampling sites located inside and outside the modeled freshwater impact polygons (Fig. 7). Overall, they show an extensive decline in oyster populations across all size classes and in both assessed basins. Within these polygons, densities of seed and marketsized oysters decreased in Black Bay/Breton Sound, and densities of spat and market-sized oysters decreased in Barataria Bay (Table 2). The decline extended over a large area of likely oyster habitat in Black Bay/Breton Sound $\left(280 \mathrm{~km}^{2}\right)$ and Barataria Bay $\left(199 \mathrm{~km}^{2}\right)$ and resulted in a total market equivalent loss of $1.19 \times 10^{9}$ oysters across the freshwater impacted areas. Spat densities remained unchanged in
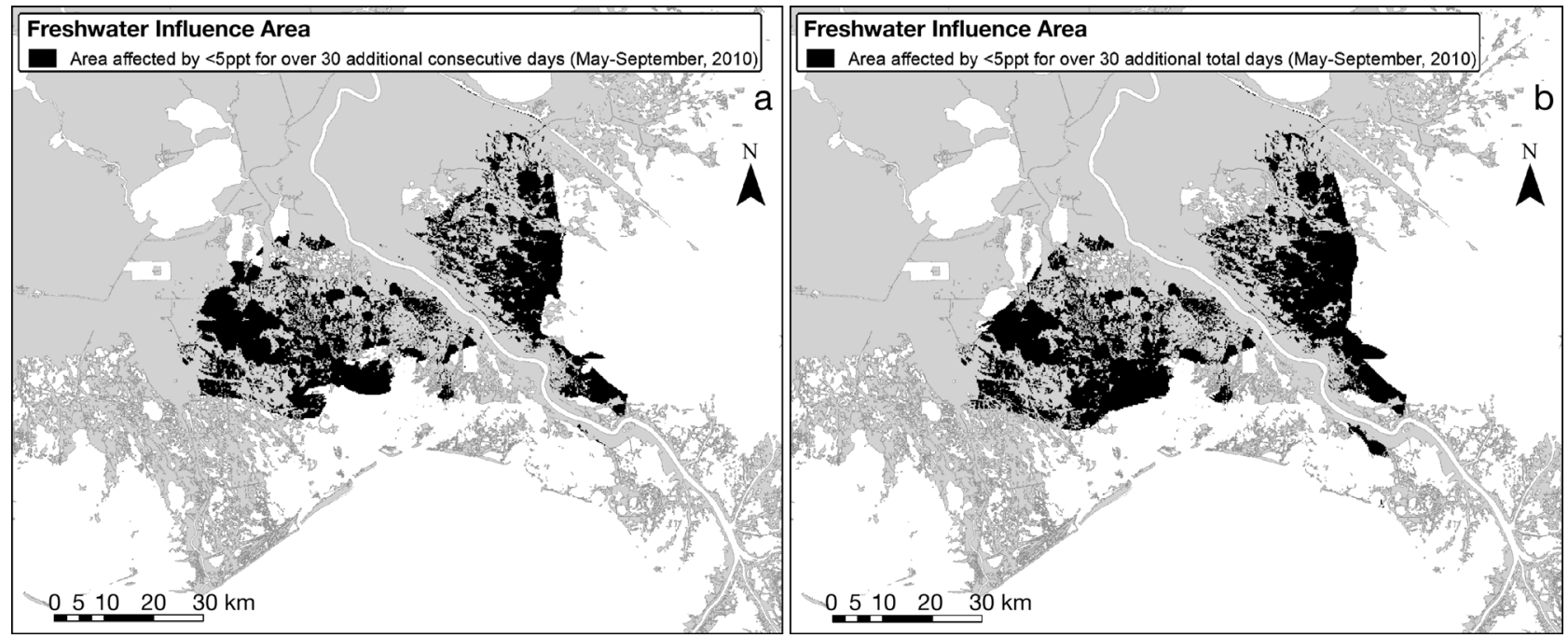

Fig. 7. Areas experiencing more than 30 additional days of salinities < 5 ppt from May to September 2010, compared to the average number of days $<5$ ppt over the same period between 2006 and 2009. Areas of maximum freshwater influence estimated using (a) consecutive days of salinity $<5$ ppt and (b) total days of salinity $<5$ ppt 
Black Bay/Breton Sound $\left(0 \mathrm{~m}^{-2}\right)$. Seed densities increased slightly in Barataria Bay (Table 2). This small increase was considered as a case of 'no injury' and treated as a 0 in our injury calculations.

The Nestier tray/NRDA method also showed clear declines in oysters across all size classes. Predicted post-spill densities were lower for each size class (except oyster spat in Black Bay/Breton Sound, which were 0 before and after). The largest losses were seen in seed-sized oysters in both basins (Table 2), although decreases in market-sized individuals were also notable. These density declines would be expected to occur across large areas in Barataria Bay $\left(766 \mathrm{~km}^{2}\right)$ and Black Bay/Breton Sound $\left(591 \mathrm{~km}^{2}\right)$ based on the $5 \mathrm{ppt}$ freshwater injury polygon. Unlike the previous injury estimates, we were able to create more spatially explicit injury estimates in each of the known and likely oyster habitats by predicting survival based on estimated salinities in each $200 \mathrm{~m}^{2}$ grid. This approach yielded a loss of 2.78 $\times 10^{9}$ market equivalent oysters.

\section{DISCUSSION}

Nearshore ecosystems often act as repositories for contaminants released into the open ocean and rivers. Key to mitigating the ecosystem damage caused by the deposition of oil and other contaminants is often a swift response. In many cases, postspill assessments of injury have indicated large impacts from the response activities (e.g. high pressure washing of the rocky intertidal during the 'Exxon Valdez' oil spill cleanup, see Driskell et al. 2001). The geographic extent (1000s of $\mathrm{km}$ of potentially impacted beaches and marshes) and duration (87 d of oil release) of the DWH oil spill necessitated unprecedented response and clean-up activities. The responses included the widespread uses of vast quantities of dispersants at sea, digging and disposing of beach sands, burning of oil at sea and in the marsh, extensive flushing of marshes with estuarine water, and a host of novel large-scale manipulations of hydrography and geomorphology (Martínez et al. 2012, Park et al. 2014). The large-scale introduction of freshwater from diversion structures is a novel approach to mitigation and one that our analysis suggests should be more thoroughly examined for future oil spills.

All 3 estimates of injury indicated substantial losses (over 1 billion market equivalent-sized oysters) resulting from the late spring/summer release of large quantities of freshwater from diversion structures in
2010. Loss of oysters from the release of freshwater and consequent decreases in salinity is not a new phenomenon; extensive literature has documented negative impacts of low salinities on oysters (Chatry et al. 1983, Melancon et al. 1998, Turner 2006, La Peyre et al. 2009, Soniat et al. 2013). The extent of the loss in 2010, however, was highly unusual in its magnitude, which is a direct result of the release of high volumes of freshwater at a time of high water temperatures (La Peyre et al. 2013) and the need to keep the structures open for such a long time given the unexpectedly long duration of the spill event.

Vast areas of both basins experienced prolonged low salinity that would be expected to affect oyster survival. Our comparison of the 2010 salinity data to the baseline period of 2006-2009 demonstrated a vast spatial extent $\left(100 \mathrm{~s}\right.$ of $\left.\mathrm{km}^{2}\right)$ of unusually lowsalinity waters resulting from the diversion discharges. The injury polygon used for the NRDA spatial analysis defined the area that would lead to loss of oysters due to salinities $<5$ ppt for more than 30 consecutive days. This level is consistent with literature findings that extended periods of low salinities result in extensive high oyster mortality. In our study, this threshold is also supported by the extensive Nestier tray data collected by the State of Louisiana.

Although we chose a threshold of 5 ppt for consecutive days, most of the oligohaline and mesohaline areas were near 1-3 ppt for the vast majority of the summer as a result of the continuous high discharge from the diversion structures. Our results are likely conservative because our decision to estimate exposure based on consecutive days of low salinity likely underestimates the full area impacted by decreased salinities in 2010 versus the historical baseline. The areas in the total days polygons are somewhat larger and hence would give a larger injury estimate.

Of the 3 approaches used, the fisheries temporal method is the simplest. This approach compared the average of baseline densities (2006-2009) to the average after the spill in 2010 at fixed stations. Changes in density were assumed to be a result of the unique conditions in 2010. This approach yielded the highest injury estimate of $3.2 \times 10^{9}$ market equivalent oysters lost. The before/after aspect of this analysis is used in many types of environmental assessment (see Schmitt \& Osenberg 1996) and controls for spatial variability by holding sites fixed over time. The limitation of the design is the lack of control or reference areas to contrast to the area of impact. Restricting the fisheries temporal approach to the area within the $5 \mathrm{ppt}$ freshwater impact area decreased the injury estimate by over $60 \%$ (3.2 vs. 
$1.1 \times 10^{9}$ market equivalent oysters). This substantial decrease in the injury estimate probably represents a separation of the zone of complete mortality from extreme low salinity from areas that were more marginally impacted. Evidence for this is the overall increase in market size oysters in Barataria Bay. Closer inspection of the site pattern revealed some locations where larger oysters were seemingly unaffected by the extreme low-salinity areas. Such areas may have experienced periodic refuges of salt water because of their closer proximity to inlets or deepwater channels.

Our second approach to injury assessment, the NRDA spatial analysis, benefits from a design that delineates reference and impact sites in the same year. Sampling areas inside the polygon experiencing 5 ppt for $>30$ consecutive days served as the impact sites and those outside the polygon (but within the affected basins) served as our references, allowing us to control for basin-wide effects in 2010 . Decreases in densities were evident in all size classes of oysters, with the exception of seed-size oysters in Barataria Bay. Applying the change in density over the area of our impact polygon resulted in an injury estimate of $1.2 \times 10^{9}$ market equivalent oysters lost. The magnitude of this estimate agrees with the fisheries temporal approach when restricted only to the 5 ppt exposure polygon. Despite differences in site selection criteria between the LDWF sampling, which serve as the basis for the fisheries temporal assessment, and the NRDA sampling, both sampling protocols used diver-collected quadrats, which likely increases the compatibility of the comparison between studies. The strength of the before/after contrast with the fisheries temporal assessment coupled with the impact/control nature of the NRDA spatial design results in a relatively robust assessment that produces remarkably similar injury estimates and serves as validation for what we conclude is the minimum injury estimate owing to the freshwater-diversion response actions.

The fisheries temporal and the NRDA spatial assessment injury approaches both have limited spatial resolution; the change in oyster density is applied to the entire injury domain. Although both estimates adjust the injury to account for differences in percent cover of oysters in the different strata (mapped oyster reef, leased areas, likely oyster habitat), a universal delta density is applied to all strata. The Nestier tray/NRDA approach offers a spatially explicit injury estimate by using stratum-specific density changes as well as stratum-specific oyster percent cover estimates. The approach also uses the dose-response curve generated from the LDWF Nestier tray study to predict pre-spill oyster densities.

While the results of the different approaches to estimating injury are consistent in direction and rough magnitude, uncertainty exists in all 3 approaches and confidence intervals over the different approaches. We believe that the range 1.1 to 3.2 billion oysters lost encompasses the range of uncertainty due to measurement and procedural errors. The estimate of $2.7 \times 10^{9}$ oysters from the Nestier tray injury approach is likely the most rigorous of our estimates because of its spatially explicit nature and its use of a detailed exposure-response relationship based on studies of freshwater impacts on oysters in the same basins where the injury occurred.

The design of the NRDA subtidal oyster studies was intended to evaluate abundance of oysters throughout the area where oil was observed on shorelines and surface waters. While toxicity studies have demonstrated that exposure to oil in water from the DWH spill could also have potentially harmed oysters, confirmation of such exposure is limited. In addition, in statistical analyses attempting to relate oyster densities to NRDA-collected data on oiling (measured in terms of co-located sediment tPAH) and oil-on-water (days, frequencies, and presence/ absence), distance to heavily oiled shorelines did not support a discernable association between exposure to oil and subtidal oyster densities.

Besides oil and freshwater, several other factors known to affect oyster populations were examined during our study and were found not to offer compelling alternative explanations for the overall oyster decline observed across these 3 analyses. Competing hypotheses such as harvest pressure would not apply to 2010, since oysters were not harvested in the 2 basins as a result of public health concerns following the oil spill. Both the prevalence and severity of oyster disease (dermo) and oyster predators (such as oyster drills Thais haemostoma) would be expected to be substantively reduced by the reduction in salinities; furthermore, extensive NRDA oyster sampling and disease analysis in 2010 and 2011 showed very low prevalence of infection throughout our study area $(<2$ on a scale of 1 to 5 , where scores of 3 indicate mortality potential). Temperature was typically either constant over the period of interest or exhibited a very slight decline and contributed minimally to variation within and outside of areas of freshwater exposure; thus it is unlikely to confound our results. In addition, precipitation in 2010 did not appear to be abnormal, based on an analysis of records from the US Historical Climatology Network daily dataset; potential impacts 
from drought or from excessive rainfall lowering salinities in these basins are therefore unlikely.

Using a series of methods and multiple data sets, progressing from the simplest to more sophisticated approaches, we consistently found that post-spill densities were lower than both temporal and spatial baseline comparison density estimates. Results were robust to data sets and changes in approach. We are confident that the freshwater exposures from Louisiana diversions in 2010 produced substantial, widespread oyster mortality in both Barataria Bay and Black Bay/Breton Sound basins. Discharge records show an atypical pattern and unusually high magnitude of freshwater flow from Davis Pond and Caernarvon diversions in the late spring and summer 2010. The efficacy of releasing large quantities of freshwater in response to the approach of oil from offshore should be carefully examined given the injury to oysters that we documented in this study. Such an analysis should be holistic at the ecosystem level and include responses of other organisms and habitats within the estuary.

Acknowledgements. Funding for this study and production of this publication was provided by the Federal and State Natural Resource Agencies' (Trustees') NRDA for the DWH oil spill through the NOAA Damage Assessment, Remediation and Restoration Program (DARRP) (NOAA contract no. AB133C-11-CQ-0050). We thank Lyman McDonald and Michelle Bourassa Stahl of West, Inc., for their assistance with key design elements of the study. Finally, we dedicate this article in memory of our dear colleague and friend Amelia Geggel. The scientific results and conclusion of this publication, as well as any views or opinions expressed herein are those of the authors and do not necessarily represent the view of NOAA or any other natural resource Trustee for the BP/DWH NRDA. Any use of trade, firm, or product names is for descriptive purposes only and does not imply endorsement by the US Government.

\section{LITERATURE CITED}

Beck MW, Brumbaugh RD, Airoldi L, Carranza A and others (2011) Oyster reefs at risk and recommendations for conservation, restoration, and management. Bioscience 61: 107-116

Brown KM, Richardson TD (1988) Foraging ecology of the southern oyster drill Thais haemastoma: constraints on prey choice. J Exp Mar Biol Ecol 114:123-141

Chatry M, Dugas RJ, Easley KA (1983) Optimum salinity regime for oyster seed production on Louisiana's state seed grounds. Contrib Mar Sci 26:81-94

Coen LD, Brumbaugh RD, Brushek D, Grizzle R and others (2007) Ecosystem services related to oyster restoration. Mar Ecol Prog Ser 341:303-307

Davis HC (1958) Survival and growth of clam and oyster larvae at different salinities. Biol Bull (Woods Hole) 114: 296-307
DeLaune RD, Jugsujinda A, Peterson GW, Patrick WH Jr (2003) Impact of Mississippi River freshwater reintroduction on enhancing marsh accretionary processes in a Louisiana estuary. Estuar Coast Shelf Sci 58:653-662

*Driskell WB, Ruesink JL, Lees DC, Houghton JP, Lindstrom SC (2001) Long-term signal of disturbance: Fucus gardneri after the Exxon Valdez oil spill. Ecol Appl 11: 815-827

Duke RW Jr (2008) Oyster survival and growth within the Barataria Estuary. MSc thesis, Nicholls State University, Thibodaux, LA

*Fodrie JF, Kenworthy MD, Powers SP (2008) Unintended facilitation between marine consumers generates enhanced mortality for their shared prey. Ecology 89: 3268-3274

Grabowski JH, Brumbaugh RD, Conrad R, Keeler AG and others (2012) Economic valuation of ecosystem services provided by oyster reefs. Bioscience 62:900-909

Gunter G (1955) Mortality of oysters and abundance of certain associates as related to salinity. Ecology 36:601-605

Gunter G (1979) Studies on the southern oyster borer, Thais haemastoma. Gulf Res Rep 6:249-260

La Peyre MK, Gossman B, La Peyre JF (2009) Defining optimal freshwater flow for oyster production: effects of freshet rate and magnitude of change and duration on eastern oysters and Perkinsus marinus infection. Estuaries Coasts 32:522-534

* La Peyre MK, Eberline BS, Soniat TM, La Peyre JF (2013) Differences in extreme low salinity timing and duration differentially affect eastern oyster (Crassostrea virginica) size class growth and mortality in Breton Sound, LA. Estuar Coast Shelf Sci 135:146-157

* LDNR (Louisiana Department of Natural Resources) (2003) Caernarvon freshwater diversion. Project Annual Report 2003. http://lacoast.gov/reports/project/3890674 1.pdf

LDWF (Louisiana Department of Wildlife and Fisheries) (2006) Oyster stock assessment report of the public oyster areas in Louisiana: seed grounds, seed reservations, and conditionally managed areas. Oyster Data Report Series No. 12. LDWF, Baton Rouge, LA

LDWF (2007) Oyster stock assessment report of the public oyster areas in Louisiana: seed grounds and seed reservations. Oyster Data Report Series No. 13. LDWF, Baton Rouge, LA

LDWF (2008) Oyster stock assessment report of the public oyster areas in Louisiana: seed grounds and seed reservations. Oyster Data Report Series No. 14. LDWF, Baton Rouge, LA

LDWF (2009) Oyster stock assessment report of the public oyster areas in Louisiana. LDWF, Baton Rouge, LA

LDWF (2010) Oyster stock assessment report of the public oyster areas in Louisiana: seed grounds and seed reservations. Oyster Data Report Series No. 16. LDWF, Baton Rouge, LA

K Lindstrom J, Szpiro AA, Sampson PD, Sheppard L, Oron A, Richards M, Larson T (2011) A flexible spatio-temporal model for air pollution: allowing for spatio-temporal covariates. UW Biostatistics Working Paper Series, Working Paper 370. http://biostats.bepress.com/uwbiostat/ paper370

Martínez ML, Feagin RA, Yeager KM, Day J and others (2012) Artificial modifications of the coast in response to the Deepwater Horizon oil spill: quick solutions or longterm liabilities? Front Ecol Environ 10:44-49

McDonald T, Telander A, Marcy P, Oehrig J, Geggel A 
(2015) Temperature and salinity estimation in estuaries of the northern Gulf of Mexico. NOAA Tech Rep. https:// www.fws.gov/doiddata/dwh-ar-documents/863/DWHAR0270936.pdf

Melancon E, Soniat T, Cheramie V, Dugas R, Barras J, Lagarde M (1998) Oyster resource zones of the Barataria and Terrebonne estuaries of Louisiana. J Shellfish Res 17:1143-1148

Park K, Powers SP, Bosarge GS, Jung HS (2014) Plugging the leak: Barrier island restoration following Hurricane Katrina enhances larval retention and improves salinity regime for oysters in Mobile Bay, Alabama. Mar Environ Res 94:48-55

Peterson CH, Grabowski JH, Powers SP (2003) Estimated enhancement of fish production resulting from restoring oyster reef habitat: quantitative valuation. Mar Ecol Prog Ser 264:249-264

Piehler MF, Smyth AR (2011) Habitat-specific distinctions in estuarine denitrification affect both ecosystem function and services. Ecosphere 2:art12

Roman H, Stahl MS (2015) Estimation of oyster resource in the northern Gulf of Mexico. NOAA DWH NRDA Tech Rep. https://www.fws.gov/doiddata/dwh-ar-documents/ 863/DWH-AR0270324.pdf

Rose KA, Huang H, Justic D, de Mutsert K (2014) Simulating fish movement responses to and potential salinity stress from large-scale river diversions. Mar Coast Fish 6:43-61 Schmitt RJ, Osenberg CW (eds) (1996) Detecting ecological

Editorial responsibility: Charles Peterson, Morehead City, North Carolina, USA impacts: concepts and applications in coastal habitats. Academic Press, New York, NY

Scyphers SB, Powers SP, Heck KL Jr, Byron D (2011) Oyster reefs as natural breakwaters mitigate shoreline loss and facilitate fisheries. PLOS ONE 6:e22396

Soniat TM, Brody MS (1988) Field validation of a habitat suitability index model for the American oyster. Estuaries 11:87-95

Soniat TM, Klinck JM, Powell EN, Cooper N and others (2012) A shell-neutral modeling approach yields sustainable oyster harvest estimates: a retrospective analysis of the Louisiana state primary seed grounds. J Shellfish Res 31:1103-1112

Soniat TM, Conzelmann CP, Byrd JD, Roszell DP, Bridevaux JL, Suir KJ, Colley SB (2013) Predicting the effects of proposed Mississippi River diversions on oyster habitat quality: application of an oyster habitat suitability index model. J Shellfish Res 32:629-638

Soniat TM, Cooper N, Powell EN, Klinck JM and others (2014) Estimating sustainable harvests of eastern oysters, Crassostrea virginica. J Shellfish Res 33:381-394

* Szpiro AA, Sampson PD, Sheppard L, Lumley T, Adar SD, Kaufman JD (2009) Predicting intra-urban variation in air pollution concentrations with complex spatio-temporal dependencies. Environmetrics 21:606-631

Turner RE (2006) Will lowering estuarine salinity increase Gulf of Mexico oyster landings? Estuaries Coasts 29: $345-352$

Submitted: May 9, 2016; Accepted: April 7, 2017

Proofs received from author(s): May 22, 2017 